\title{
SYMPOZJUM Z OKAZJI OTWARCIA MUZEUM W SANKTUARIUM MARKI BOŻEJ KĘBELSKIEJ W WĄWOLNICY. WĄWOLNICA 22 CZERWCA 2013.
}

W Wąwolnicy, położonej na obrzeżach Kazimierskiego Parku Narodowego, na trasie prowadzącej z Lublina przez Nałęczów do Kazimierza Dolnego, znajduje się jedno z najbardziej znanych sanktuariów. Sama miejscowość, a przede wszystkim Parafia św. Wojciecha w Wąwolnicy - kojarzona jest przez wiernych obrządku rzymskokatolickiego z miejscem kultu Matki Boskiej Kębelskiej.

W dawnej kaplicy zamkowej, wzniesionej jeszcze w czasach króla Kazimierza Wielkiego, ustawiona jest w ołtarzu głównym łaskami słynąca figura Matki Bożej z Dzieciątkiem, której powstanie datuje się na ok. 1440 r. Poniżej, w dolnej kondygnacji kaplicy - w dawnej krypcie - znajduje się muzeum, w którym umieszczono eksponaty świadczące o bogatej historii miejscowości i parafii.

Muzeum otwarte 24 czerwca 1994 roku, powstało z inicjatywy ówczesnego proboszcza księdza Infułata Jana Pęzioła i Zarządu Towarzystwa Przyjaciół Wąwolnicy. W związku z przeprowadzanymi w ostatnich latach pracami konserwatorskimi na terenie parafii przystąpiono do remontu kaplicy, a także zaaranżowano na nowo ekspozycję muzealną według projektu mgr Elżbiety Kasprzyk i dr Beaty Skrzydlewskiej.

W niewielkim pomieszczeniu, zaprezentowano - jak w mikrokosmosie - historię regionu od czasów wczesnego średniowiecza aż po dzień dzisiejszy.

Z okazji otwarcia na nowo Muzeum w Sanktuarium Matki Bożej Kębelskiej dnia 22 czerwca 2013 roku, Parafia św. Wojciecha w Wąwolnicy, Katedra Muzealnictwa KUL, Katedra Kultury Artystycznej KUL i Fundację Kazimierza Wielkiego w Lublinie zorganizowały uroczyste Sympozjum, które rozpoczęło się modlitwą przed figurką Matki Bożej Kębelskiej. Obrady odbywały się w sali konferencyjnej Domu Pielgrzyma.

W doborze referatów uwzględniono wszystkie najistotniejsze problemy odnoszące się do historii Wąwolnicy i samego Sanktuarium.

Sympozjum przewodniczyła dr hab. Bożena Kuklińska, prof. KUL. Gości powitał i słowo wstępne wygłosił proboszcz parafii ks. kanonik Jerzy Ważny. 
Jako pierwszy głos zabrał dr Piotr Makarzec, przewodniczący Fundacji Kazimierza Wielkiego, jego referat nosił tytuł Rozwój miasta Wawolnicy.

Dzieje Sanktuarium Matki Bożej Kebelskiej - omówił ks. Infułat Jan Pęzioł, zaś o Kompetencjach kulturowych parafii, mówił prof. dr hab. Sławomir Partycki z Instytutu Socjologii KUL.

Dalsza część sympozjum dotyczyła problemów konserwatorskich a także historii muzeum i jego zbiorów. Jako pierwsza głos zabrała mgr Barbara Stolarz, przedstawiciel Wojewódzkiego Urzędu Ochrony Zabytków w Lublinie, mówiła o Historycznym i konserwatorskim rozpoznaniu wnętrza Kaplicy Matki Bożej Kębelskiej.

Dr Małgorzata Kierczuk-Macieszko, pracownik Instytutu Historii Sztuki KUL, omówiła historię i dokonała analizy porównawczej z innymi średniowiecznymi rzeźbami tego typu Figury Matki Boskiej Kębelskiej.

Nawiązując do dziejów kolekcji muzealnej i pierwszego muzeum, emerytowana nauczycielka miejscowej szkoły i zarazem opiekun muzeum Wiesława Dybała zaprezentowała referat na temat Towarzystwo Przyjaciót Wąwolnicy i jego wktad w ochronę zabytków.

W referacie Projekt i realizacja Muzeum w Sanktuarium Matki Boskiej Kębelskiej w Wawolnicy na tle wspótczesnych muzeów religijnych o muzeum obecnym mówiła dr Beata Skrzydlewska, pracownik Katedry Muzealnictwa i Ochrony Zabytków KUL.

Wystąpienia końcowe dotyczyły zbiorów znajdujących się w muzeum, muzealia ukazane zostały na szerszym tle kulturowym.

Obiekty archeologiczne zaprezentowała w referacie Pradzieje okolic Wawolnicy - dr hab. Anna Zakościelna z Instytutu Archeologii UMCS, zaś postać i dzieła Józefa Gosławskiego omówił mgr Marcin Markowski, doktorant KUL, w referacie Projekty monet Polskiej Rzeczypospolitej Ludowej autorstwa Józefa Gostawskiego. 


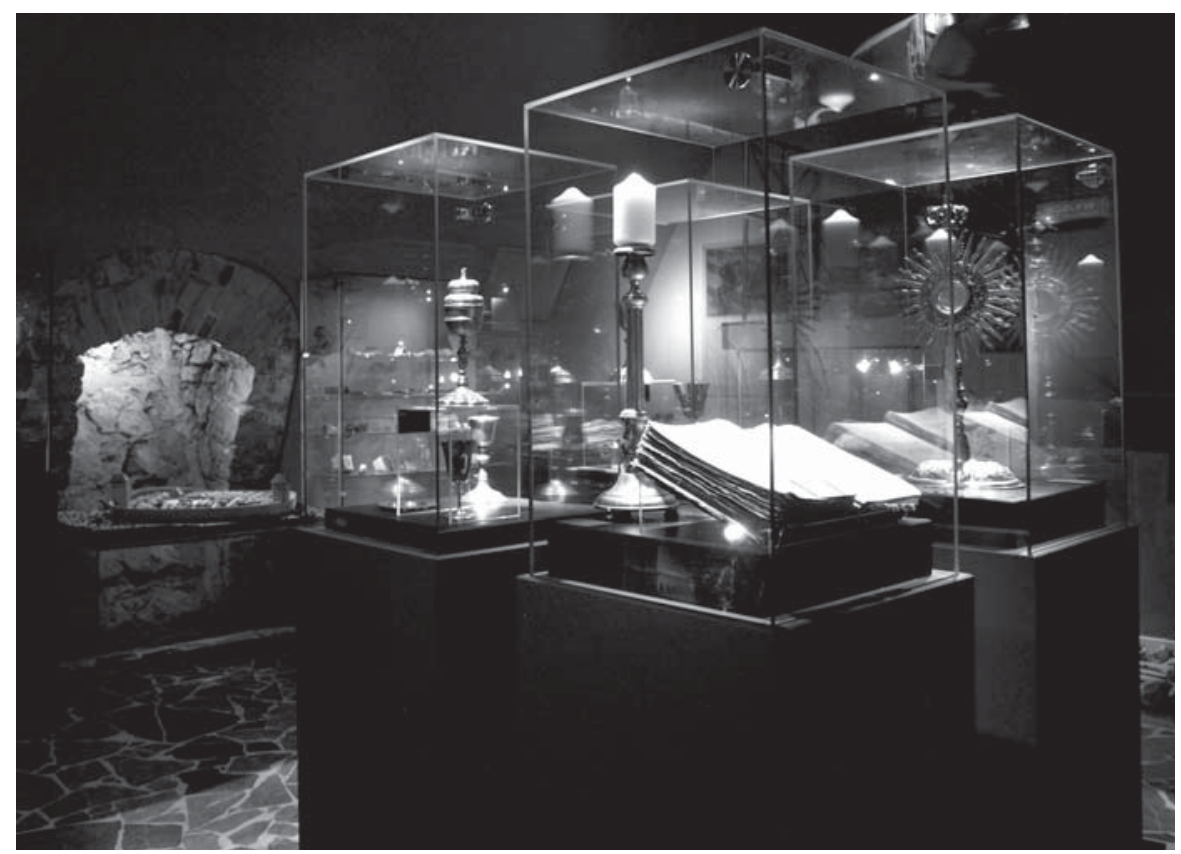

Fot 1. Muzeum w Wąwolnicy. Ekspozycja złotnictwa. Fot. Beata Skrzydlewska.

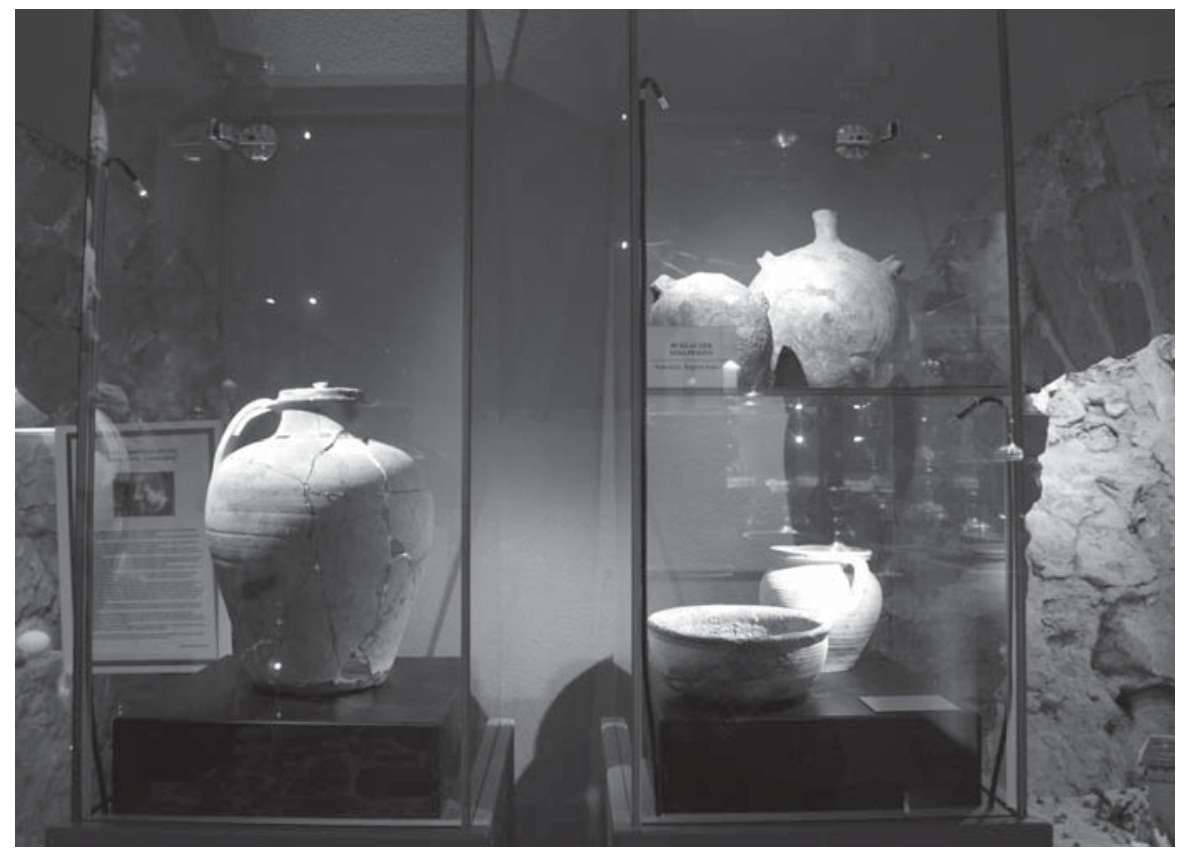

Fot. 2. Muzeum w Wąwolnicy. Ekspozycja archeologiczna. Fot. Beata Skrzydlewska. 